Нурсеитова $\Lambda . A$.

Қазіргі кезеңдегі жапон қоғамындағы гендерлік саясат

Nurseitova L.D.

\section{Gender politics in modern japanese society}

Нурсеитова $\Lambda . A$.

Гендерная политика в современном японском обществе
Шығыстың дамыған мемлекеттерінің бірі Жапон елінде дәстүрлі және жаһандық үрдістердің кең етек жайып, халықаралық байланыстардың дамуы қарқынды жүріп жатқан заманда, елдің тарихи, мәдени, әлеуметтік даму жолында әйелдердің рөлі маңызды мәселелерАің бірі болып табылады.

XX ғ. соңы мен XXI ғ. қоғамдық-экономикалық қатынастардың тез қарқынмен дамуы, әйелдердің ерлерден қалыспай тең дәрежеде жоғары білім алуы, әйелдер мен ерлер арасындағы тең құқықтық, заң жүйесінің орнатылуы, әйелдердің мемлекеттің қоғамдық-экономикалық саясатына белсене қатысуы, біліктілігінің нығаюы, ғасырлар бойы дамыған отбасы сияқты дәстүршілдік құндылықтарының өзгеріске ұшырай бастауына байланысты күншығыс елінің әйелдер мәсемесін зерттеуге негіз болды.

Бұл мақалада автор қазіргі кезеңдегі жапон қоғамындағы әйелАердің рөлін жан-жақты қарастырған.

Түйін сөздер: гендер, жапон әйе^дері, қазіргі кезең, демократия, БҰҰ, екінші дүниежүзілік соғыс, теңдік, тәуелсіз, білім, құқық.

The women role in modern Japanese society, carried out in a conditions of traditional and cultural globalization. Female factor persistently breaks into the modern world view. The role of Japanese women is a major challenge in terms of the dynamics of socio-economic and political development of Japanese society in the XXI century.

Now days the Japanese women leave their old place in their family and appear on public stage as an independent force of global civilization. This article discusses the changes and developments of the role of women in modern Japanese society.

Key words: gender, Japanese women, modern period, democracy, UN, World War II, equality, independence, education, rights.

В современных условиях роль женщины в японском обществе осуществляются в условиях традиционной и культурной глобализации. Женский фактор настойчиво врывается в современную картину мира. Роль японской женщины является главной задачей в условиях Аинамики социально-экономического и политического развития японского общества в XXI веке. В данной статье рассматривается развитие роли женщин в современном Японском обществе.

Кмючевые слова: гендер, японские женщины, современный период, демократия, ООН, вторая мировая война, равноправие, независимость, образование, право. 


\section{ҚАЗІРГІ КЕЗЕҢАЕГІ ЖАПОН ҚОҒАМЫНААҒЫ ГЕНАЕРАІК САЯСАТ}

XX ғ. соңы мен XXI ғ. қоғамдық-экономикалық қатынастардың тез қарқынмен дамуы, әйелдердің ерлерден қалыспай тең дәрежеде жоғары білім алуы, әйелдер мен ерлер арасындағы тең құқықтық заң жүйесінің орнатылуы, әйелдердің мемлекеттің қоғамдық-экономикалық саясатына белсене қатысуы, біліктілігінің нығаюы, ғасырлар бойы дамыған отбасы сияқты дәстүршілдік құндылықтарының өзгеріске ұшырай бастауына байланысты күншығыс елінің әйелдер мәселесін зерттеуге негіз болды.

Қазіргі таңда жапон қоғамында дәстүршілдік қатынастың терең тамыр жайғанына қарамастан, мемлекеттің тұрақты дамуын алға қойған жапон үкіметі қоғамдық-экономикалық қатынасты дамыту үшін, әйелдердің қоғамдағы рөлінің маңыздылығын жан-жақты қарастыруда.

Жапон елінің қоғамдық-экономикалық, отбасы жүйесінің дамуында, әйелдердің алатын рөлі ерекше. Дегенмен, қазір қоғамдағы әйелдер рөлі, әйелдер теңдігі төңірегіндегі шетелдік және ресейлік ғалымдардың еңбектеріне талдау жасай отырып, аталмыш мәселенің әлемнің ешбір елінде осы кезге дейін толық шешімін таппағандығына көз жеткізуге болады. Әйелдер мәселесі, әсіресе гендерлік теңдік бұрынғысынша қоғамдық таластардың өзекті тақырыбы және демократия мен адам құқығының сақталу жолына бет алған мемлекеттердің әлеуметтік саясатының мақсаты болып табылады.

Әйелдер мәселесі бірқатар халықаралық құжаттарда: БҰҰның «Әйелдерге байланысты кемсітушіліктің барлық нысандарын жою туралы» Конвенциясында, Найробиялық «1986-2000 жылдардағы кезеңдегі әйелдер жағдайын жақсарту саласындағы сәулетті болашақ әрекетінің стратегиясында», 1995 жылғы «Теңдік, даму, бейбітшілік мүддесіндегі әрекет» ұранымен өткен IV Бүкіл әлемдік әйелдердің Токио конференциясының материалдарында қойылып тұр.

Жапон ғалымдарының зерттеулеріне келер болсақ, У.Тадао, А.Муцуко, Ц.Миеко, В.Кумата, И.Юдзава, Б.Марико жалпы екінші дүниежүзілік соғыстан кейін жапон әйелдер бейнесінің өзгеріске ұшырауын, жапон қоғамында гендер саясатының дамуын, жаһандық кезеңдегі әйелдер мәселесін жан-жақты зерттеп қарастырған. Жапон елінде әйелдер мәселесіне зор үлес 
қосқан, сонымен қатар осы мәселеге қатысты көп еңбек жазған Сумико Ивао профессорды атап өткен жөн. Сумико Ивао профессордың «Японская женщина свободнее мужчины» атты еңбегінің аталмыш мәселедегі маңыздылығы зор.

Сумико Ивао өз еңбектерінде соғыстан кейін жапон әйелдер жағдайының өзгеріске ұшырауын, сонымен қатар соңғы кезде жапон қоғамында әйелдердің әлеуметтік рөлінің нығаюын қарастырған.

Жапон тарихнамасында әйелдер саясатының қалыптасуы, өзгеруі және дамуы елдің әлеуметтік - экономикалық қатынастардың өзгеріп, дамуымен тығыз байланысты. Жапон қоғамында әйелдер рөлінің тарихнамасына тоқталатын болсақ, жапон деректері бойынша, әйелдер саясатының бастамасын көне заманға жатқызамыз. Бұл кезеңде қоғам матриархалдық жүйе арқылы дамыған. Отбасы мүлкімен әйелдер иемденгендіктен, құқықтың басым бөлігі әйелдердің еншісінде болды. Қоғамдық қатынаста ерте дәуірде жапон әйелдері ерлерден қалыспай белсене ат салысып, мемлекетті императрицалар басқарған болатын. Билік еткен императрицалардың атаулары және билік еткен жылдары: Суйко (593628); Когеку (642-645); Саймэй (655-661); Дзито (686-697); Гэммэй (707-715); Гэнсе (715-724); Кокэн (749-758) [1, 4].

VI ғасырдан бастап жапон еліне буддизм және конфуцишілдік діндердің енуіне байланысты, қоғамды басқару немесе жалпы басқару тізгіні ерлердің қолына көше бастады. Эдо кезеңінде Жапонияда конфуцишілдік діннің таралып, дамуы қоғамдық қатынаста ерлер мен әйелдердің рөлін айқындады. Конфуцишілдік дін бойынша әйел адам үй шаруасымен айналысуы қажет, ал үй шаруасынан тыс жұмыстардың барлығы ер адамға жүктелген.

«Ресайкэмбо» - «Жақсы әйел және даналы ана» атты ұғым «Мэйдзи» (1867-1912) кезеңінде қалыптасты. Орта ғасыр әйелдеріне үй шаруасымен шебер айналысу және баланы дүниеге әкелу міндеттері қойылса, Мэйдзи кезеңінен бастап әйелдерге балаларына білім беру міндеті қосылды. Сонымен қатар осы кезеңде әйелдер оқытушы қызметіне жарамды, әрі лайық болып есептелді $[2,15]$.

Мемлекеттің ашылуынан кейін, оның тез қарқынмен дамуы, әйелдердің еңбекқорлық қасиетіне байланысты болды. Өйткені, Жапонияның әйелдері тоқыма тоқу кешенін дамыту арқылы және оны шетелге шығарудың арқасында, мемлекетке көп мөлшерде кіріс әкеліп, өндірістің жаңа технологияларын игеруге жағ- дай жасады. Жаңа технологияларды, елде өңдеп қайтадан шығарудың арқасында жапон экономикасы көп мөлшердегі табыстарға қол жеткізді. Елге көп мөлшерде табыс әкелген модернизация саясаты, жапон әйелдерінің арқасында да жүзеге асты деуге болады $[3,13]$.

Әйелдер мәселесіндегі түбірлі өзгерістер екінші дүниежүзілік соғыстан кейін байқала бастады. Демократиялық ағымды қолдағандар феодалдық заңдардың қалдығын жойып, жапон еліне батыс үлгісіндегі демократиялық жаңартулар енгізу керек деген ұстанымдар көбейе бастады. 1946 жылы әйелдер алғаш рет заңды түрде сайлауға қатысты, 1947 жылы жаңа конституция қабылданып, 1948 жылы жаңа азаматтық кодекс орнатылды. Соғыстан кейінгі реформалар әйелдерге көптеген жеңілдіктер алып келді, жаңа конституция әйелдерді ерлермен тең дәрежедегі құқықпен қамтамасыз етті [3, 64].

Соғыстан кейінгі экономикалық, әлеуметтік процестер жапондықтардың өмір сүру жағдайларына өшпес із қалдырды деуге болады. Өйткені, жапон әйелдері үшін, осы өзгерістердің салдарынан еңбек рыногына шығу қажеттілігі туындады. Урбанизацияның күшеюі, капиталистік қатынастардың нығаюы, ауылды жерлерде патриархалдық отбасы жүйесін жойып, орнына кішігірім отбасы жүйесінің пайда болуына әкеп соқты.

Қазіргі кезеңде жапон әйелдерінің жаңа ұстанымдары қоғамдағы, қызметтегі, отбасындағы рөлдерін күшейтуде. Жапон әйелдерінің теңдікке күрес жолы, дербес немесе тәуелсіз әйелдерге айналу құбылысы дәстүршілдік қоғамда іске асып келеді [4].

Қазіргі таңдағы жапон әйелдерінің әлеуметтік және отбасындағы бейнесін анықтауда жапон әйелдеріне жүргізген әлеуметтік сауалнама зерттеу жұмысына негізгі арқау болды. Әлеуметтік сауалнама Цукуба қаласында тұратын әйелдерге қойылды. Әлеуметтік сауалнамада қойылған сұрақтар: 1) қазіргі әйелдерге карьера құру маңызды деп ойлайсыз ба, 2) жоғары білім меңгеруде қандай деңгейге жеткіңіз келеді, 3) болашақта тұрмысқа шығуды қалайсыз ба, тұрмысқа шықсаңыз, неше жаста тұрмыс құрған дұрыс деп ойлайсыз, 4) тұрмысқа шыққаннан кейін жұмысты жалғастыра аламын деп ойлайсыз ба, 5) ата-анаңызбен тұрасыз ба, 6) анаңызға үй шаруасында көмектесесіз бе, 7) анаңыз қанша жасында тұрмыс құрған, 8) бауырларыңыз, сіңлілеріңіз бар ма, 9) анаңыз жоғары оқу орнын бітірген ба, 10) анаңыз жұмыс істейді ма, 11) болашақта қандай жұмыс атқарғыңыз келеді, 12) болашақта қандай 
жұмыста әйелдердің саны өседі деп ойлайсыз, 13) жұмысқа орналассаңыз бір фирмада ұзақ уақыт жұмыс істей аламын деп ойлайсыз ба, 14) фирмаларда әйелдерге қатысты дискриминация бар деп ойлайсыз ба, 15) жапон үкіметі ерлер және әйелдердің еңбекақысы тең деген келісім шарт қабылдаған болатын, осы заң жұмыс орындарында іске асады деп ойлайсыз ба, 16) қазіргі жапон әйелдері өз тұрмыстарымен қанағаттанама? Сауалнама нәтижесі арқылы жапон әйелдер мәселесіне қатысты мынандай қорытынды жасалынды. Қазіргі таңда жапон әйелдеріне мансап куу маңызды болып табылады. Себебі, мансап құру арқылы әйелдердің тұрмыстағы мүмкіншіліктері көбейеді, карьера құру арқылы әйелдер белгілі бір салада өз шеберліктерін тауып, дамыта алады. Қазіргі жапон әйелдері жоғары мамандық алуда магистратура деңгейін бітіруді мақсат етуде. Жапон әйелдерінің тұрмысқа шығу жасын қарастыратын болсақ, жүргізілген сауалнама нәтижесінің көрсеткіші бойынша, қазір жапон әйелдері көбінесе 30 жастан асқан кезде тұрмысқа шығуды қалайды. Жапон әйелдерінің 1980 ж. және 2009 ж. тұрмысқа шығу жасында үлкен айырмашылық бар екендігі анықталды. 1980 жылдары әйелдердің тұрмысқа шығудағы орташа көрсеткіші 22-25 жасты құраған, ал қазіргі орташа көрсеткіш 30 жасты құрайды. Бұл дегеніміз қазіргі таңдағы жапон әйелдері жоғары мамандық меңгеріп, қызметінде, тұрмысында белгілі бір тұрақтылыққа жеткен кезде ғана отбасын құруды көздейтіні анықталды. Қазіргі жапон әйелдері өмірін тұрақты жұмыспен, кіріспен қамтамасыз ету үшін жұмыс орындарында белсенділіктерін және біліктіліктерін нығайтуда. Мансабында белгілі бір деңгейге жету үшін аянбай білім алып, еңбек етуде. Жапон әйелдерінің қоғамдағы рөлдерінің дамуы нәтижесінде қазір жапон қоғамында кеш тұрмысқа шығатын әйелдер саны көбейіп, туу саны азаюда. Сауалнама нәтижесінде жапон әйелдерінің еңбек саласындағы үлесі анықталды. Мысалы, қазір қызмет көрсету саласында, кәсіпкерлік салаларда әйелдердің үлес салмағы жылдан жылға көбеюде.

Қазіргі таңда қоғамда, саясатта жапон әйелдер беделінің өсуі, біліктілігінің артуы жаңа заман үрдісінің белгісі.

XXI ғ. әлем қоғамының дамуы тез қарқынды болатыны жайлы көптеген ғалымдар болжам жасаған. Әйелдердің тәуелсіздікке ұмтылуы, еңбек нарық саясатымен шұғылдануы, кәсіпкерлікпен айналысуы осы болжамға дәлел болып табылады. Әйелдердің кәсіпкерлікпен айналысуын зерттеген американың ұлы зерттеушілерінің бі- pi Р.Петерсон және К.Вермейер бұл феноменді «бүкіл әлем көлемінде өтіп жатқан тыныш революция» деп атады. Шынымен де қысқа тарихи мерзімнің ішінде әйелдер жоғары, сапалы квалификация алып, жалдамалы жұмысшылардың қатарын толтырып, қызмет көрсететін жеке кәсіпорындарын ашып, өзінің дәстүрлі отбасы рөлдерінен ауытқып, үйлерінен тыс жұмыс атқара бастады.

«Тыныш революцияның» екі кезеңін атап көрсетуге болады: 1-кезең 50-70 жылдар әйелдердің жаппай жалдамалы еңбек саласына келуімен ерекшеленеді, 2-кезең 70 жылдың ортасынан басталады, әйелдердің дербес, өз алдына кәсіпкерлікпен айналысуы. Алғашқы кезеңді анықтайтын негізгі факторлар: әйел білімінің дамуы, азаматтық еркіндікке күресі, индустриалдық қоғамдағы ірі кәсіпорын кешендері әйелдердің еңбек күшіне тәуелді болды $[5,57]$.

XXI ғ. болашақты болжайтын «футурологтардың» айтулары бойынша жаңа ғасыр әйелдердің ғасыры болып табылады. Осыдан ғасырлар бойы қоғамдық істерден, шығармашылық, әрі еңбек жұмыстарынан алшақ өмір сүрген әйелдер жаңа заманның дамуына қандай жағдайлар жасай алады деген сұрақ туындайды. Футурологтардың жасаған зерттеу жұмыстарының нәтижесі, қазіргі таңда әйел адамның кәсіпкерлік қызметі макроэкономикаға бірталай жетістіктер әкелгені жайлы дәлелдемелер бар:

- ұлттық экономикалық құрылыстың жаңадан қалыптасып, дамуына маңызды ықпал етуде;

- даму үрдісін ынталандыруда, дамудың жаңа динамикалық күшінің бар екендігін алға қоюда;

- ұлттық өнім құндылығының нарықта қажеттілігін, сұранысын дамытуды көздеуде;

- әлеуметтік-экономикалық өзгерістерге орай саяси тұрақтылықта маңызды фактор деп ұсынуда.

Әлемнің ақпараттық қоғамға тереңдей енуіне байланысты, америка ғалымдарының айтуы бойынша «жаңа қоғамды әйелдер қалыптастырады» деген зерттеулер бар [6, 68].

Қазіргі таңда жапон қоғамында әйелдер рөлі жоғарылап, отбасы және қызметте әйелдерге деген дискриминациялық қатынас немесе қысым азайып, әйелдердің көптеген салаларда мүмкіншіліктері нығайып, қоғамдық жүйенің көптеген салалары өзгерістерге ұшырауда. Бұндай жағдай, қазіргі әлеуметтанушылардың айтуы бойынша қазіргі заманға тән жаһандық құбылыстардың бірі.

Қазіргі таңда жапон әйелдерінің болашақ ұрпақтары тәрбиеленуде. Білім деңгейі жоғары, 
өз тұрмысын қамтамасыз ететін, тұрмыс құруда асықпайтын, дербес, еркін өмір сүруді қалайтын, қызметте көтерілу арқылы тәуелсіз әйелдер саны, өз мүмкіндіктерін көтеруді қалайтын әйелдер саны жылдан жылға көбеюде.

Соғыстан кейін Жапон мемлекетінің дамуына жапон әйелдері де өз тарапынан біршама үлестерін қосты. Қабылданған жаңа заңдар, жапон әйелдерінің қоғамдағы орнын біршама болсын айқындады. II д. ж. соғыстан кейін қираған мемлекетті қалпына келтіруді мақсат еткен жапон әйелдері, мемлекеттің дамуына бар күш жігерін салды. Өз мақсаттарын іске асырудың тиімді жолдары ретінде отбасы мен қызметін бірдей алып жүруді жөн көрді. Бірақ қазіргі таңда қоғамның даму талабына сай әйелдер, қоғамдағы төзімділігін дәлелдеп саясатқа да араласуды мақсат етуде.

\section{Әдебиеттер}

1 Лазарев А. Женские проблемы // Япония сегодня. - Рег. -№012252 от 17.12.1993г. Издатель: Закрытое акционерное общество, ШЕФ-РЕДАКТОР: В.Перфильев. ответственный редактор А.Лазарев №2. - февраль. - М., 2010. - 4 - 7 с.

2 Жуков И.А. История Японии. Т.ІІ. 1868-1998. 2-изд., исправленное и дополненное. - М.: Иститут востоковедения PAH, 1999. - 15 - $74 \mathrm{c}$.

3 Bando Mariko «Nihonjysei seisaku». Japan, 2009. - 13-104 p.

4 Женская доля по-новому // http://www.japon.ru.

5 Японский опыт для российских реформ. Выпуск первый. - М.: МАКС ПРЕСС, 2001.- с. 56-57.

6 Голубенкова Е.В. Гендерная политика Японии. - М., 1999. - 68-69 с.

\section{References}

1 Lazarev A. Jenskie problem // Yaponiya segodnya. - Рег. -№012252 ot 17.12.1993g. Izdatel: Zakritoe aktsionernoe obshestvo, SHEF-REDAKTOR: B. Perfilev. Otvetstvenni redactor A. Lazarev №2. - fevral. - Moskva, 2010. 4 - 7 s.

2 Jukov I.A. Istoriya Yaponii. T.II. 1868-1998. 2-izd., ispravlennoe I dopolnitelnoe. M, Institut vostokovedeniya RAN, 1999. $15-74 \mathrm{~s}$.

3 Bando Mariko «Nihonjysei seisaku» Japan, 2009. 13-104 p.

4 Jenskaya dolya po-novomu // http://www.japon.ru.

5 Yaponskii opit dlya rossiiskih reform. Vypusk pervi. M.: MAKS PRESS, 2001.-56-57s.

6 Golubenkova E.V. Gendernaya politika Yaponii. Moskva, 1999.-68-69s. 